\title{
SAVARY, Olga. Anima animalis - voz de bichos brasileiros. Caraguatatuba: Letra selvagem, 2008.
}

Sergio Alves Peixoto Universidade Federal de Minas Gerais

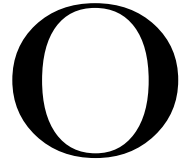

lga Savary foi, na literatura brasileira, a primeira mulher a escrever um livro de poemas tendo por temática o erotismo. $\mathrm{O}$ ano era 1982, e o livro intitula-se Magma (não confundir, infelizmente, com o decepcionante livro de poemas de Guimarães Rosa). De lá para cá, já são, com este Anima animalis, dezenove livros de poesia, da melhor poesia que se faz no Brasil de hoje, seja ela de cunho erótico, ou não.

Conceituada entre seus pares e críticos literários, não são prêmios que lhe faltam: APCA, Jabuti, Academia Brasileira de Letras, entre outros. Tradutora renomada, entre suas traduções encontramos, por exemplo, Lorca, Neruda, Borges e Otávio Paz.

Lançado em 2008, Anima animalis continua a tradição dessa poeta paraense na busca pela palavra concisa vazada em versos curtos, mais especificamente na forma do hai-kai, forma essa que ela praticamente introduziu na literatura brasileira ao traduzir, entre outros, o grande japonês Bashô. Poesia perigosa, essa, a de versos extremamente concisos; pode resultar em uma poesia anêmica. $\mathrm{O}$ que não é o caso de Olga Savary.

O livro se faz de dez animais, um bestiário mais preocupado com a poesia em si, em sua pureza que a afasta do referente, do que com 
representações dessas “bestas”. Essas representaçõos estão lá, sim, mas, é verdade, em estilizadas iluminuras, como é de praxe em um bestiário, feitas pelo gravador Marcelo Frazão, artista que deu idéia para a consecução do livro, ao convidar a poeta para emoldurar suas obras com seu verso. Além dos poemas em português, o livro traz traduções para o espanhol, o finlandês, o francês, o inglês, e o italiano. Qual a razão dessas traduções? Não sabemos. Talvez com tão poucos animais, a obra não se configurasse realmente como um livro. Uma razão prática, portanto. Um senão? A não inclusão do nome dos tradutores.

Embora o subtítulo da obra diga que se tratará, aí, no livro, das vozes de bichos especificamente brasileiros, não é bem isso o que ocorre. Também não sabemos a razão. Em ordem alfabética, eles aparecem, os dez animais escolhidos: o beija-flor, o bode, o cavalo, o jacaré, o lobo-guará, o peixe, o sapo, o tamanduá, o touro e, finalmente, o urubu. De cada um, Olga procura extrair, por intermédio de belas imagens, a essência, a voz, a alma.
Assim, do beija-flor, destacase a esperança da liberdade de voar; do bode, o erotismo de um fauno; do cavalo, poema dedicado a Mário Quintana, a beleza, já que para o poeta gaúcho, é ele o animal mais belo da natureza; do jacaré - o único poema longo do livro - as lembranças de sua terra, o Pará amazônico, com seus mitos e mistérios; do lobo-guará, como já nos mostrou a Rede Globo, a desconfiança e a esperteza do bicho em terras do Caraça mineiro; do peixe, a maravilha de conter o mar em suas guelras; do sapo, a transmutação em príncipe encantado de encantadas lendas; do tamanduá, o erotismo da língua fálica; do touro, o remanso trágico que, é pena, a poeta perde ao não se referir ao famoso animal trazido à literatura por Clarice Lispector em seu livro de contos Laços de família; finalmente, do urubu, a transmutação da morte em vida, um dos papéis que a tradição tem atribuído à arte em geral e à poesia mais especificamente.

Como dissemos no início, Olga procura tirar dos animais escolhidos, a sua voz, a sua alma, a poesia que ela vê neles. Interessante 
é perceber que o primeiro e o último poema deixam falar animais alados: o beija-flor e o urubu. A liberdade do vôo de ambos estaria configurando a liberdade da poesia que Mário de Andrade já tinha visto perdida no poema "Os cortejos" de sua Paulicéia desvairada, ao dizer que, na cidade que cresce e se moderniza as asas, a alegria e a poesia inexistem? ("Nada de asas! Nada de poesia! Nada de alegria!") Estaria Olga querendo dizer, como muitos representantes de uma poesia moderna o fizeram, que a poesia pode ser feita do belo e do feio? Do sublime e do grotesco?

Do livro, alguns poemas se sobresssaem, como é o caso de "Bode", onde vemos no verbo "homenageio", a alusão à transmutação do homem e do bode no fauno mítico:

Meu outro nome? Fauno. Não ofendo, homenageio Donzelas na mata.

$\mathrm{Ou}$, no maior deles, como figurando a desmesura da força física e do corpo, vêem-se as origens de Olga e as origens do mundo tectônico e não só amazônico. $\mathrm{O}$ poema é "Jacaré", um enigma para todos e para todo o sempre, perdido no mistério original dessa Pangéia que, segundo o Novo Aurélio, certa teoria científica diz ter sido "um continente antigo, constituído pela reunião dos atuais continentes, os quais teriam surgido pela fissuração do bloco original":

Jacaré

Jacaré de rio, do rio Amazonas e seus afluentes ao Paracatuba do belo Pará, faço tremer o chão sob os vários pés. Rujo igual leão, urro como touro, desafio à luta tudo quanto é macho. Sobrevivo às eras no sul da América do Norte, no norte da América do Sul, e ao longo do vale do rio chinês Yang-Tse. Por que só em lugares tão distantes um do outro ninguém explica ou só a Pangéia é que explica, é enigma, mistério de jacaré. 
O recurso ao bestiário foi uma escolha de Olga Savary para dar voz a determinados animais e, dessa maneira, deixar falar mais puramente sua poesia e a poesia brasileira contemporânea. Assim fazendo, nessa reduzida seleção de pequenos poemas sintéticos e imagéticos por excelência, introduzidos por iluminu(grav)uras pessoais e criativas de Marcelo Frazão, a anima do poeta se desvela no verso e pelo verso. Neles, no verso e no poema, o humano e o animal se identificam e se complementam poeticamente.

As "asas de metáfora", de "Beija-flor", que inicia o livro, e "o voar do chão até a nuvem”, do ultimo deles, "Urubu" são fórmulas nada matemáticas dessa poesia que Olga Savary mais uma vez professa. Uma poesia que, pela linguagem, que é seu corpo, permite-se alçar ao etéreo, ao imponderável, à magia. 